\title{
Bleaching of melanin in the epidermis of South American fur seal and its application on enzyme immunohistochemistry ${ }^{1}$
}

\author{
Ana Paula da Silva ${ }^{2}$, Rodrigo Godoi Silva ${ }^{2}$, Bruno Cogliati ${ }^{3}$, Alex Sander \\ Machado Dias ${ }^{2}$, Alfredo E. Le Bas ${ }^{4}$ and Francisco Javier Hernandez-Blazquez ${ }^{2}$ \\ ABSTRACT.- Silva A.P., Silva R.G., Cogliati B., Dias A.S.M., Le Bas A.E. \& Hernandez- \\ Blazquez F.J. 2011. Bleaching of melanin in the epidermis of South American fur \\ seal and its application on enzyme immunohistochemistry. Pesquisa Veterinária \\ Brasileira 31(3):267-270. Setor de Anatomia dos Animais Domésticos e Silvestres, \\ Departamento de Cirurgia, Faculdade de Medicina Veterinária e Zootecnia, Universidade \\ de São Paulo, Av. Prof. Orlando Marques de Paiva 87, São Paulo, SP 055508-900, Brazil. \\ E-mail: paulasilvabio@usp.br \\ The South American fur seal (Arctocephalus australis) is an amphibious marine mammal \\ distributed along the Atlantic and Pacific coasts of South America. The species is well \\ adjusted to different habitats due to the morphology of its fin-like members and due to \\ some adaptations in their integumentary system. Immunohistochemical studies are very \\ important to evaluate the mechanisms of skin adaptation due the differential expression of \\ the antigens present in the tissue depending of the region of the body surface. However, \\ its strongly pigmented (melanin) epidermis prevents the visualization of the immuno- \\ histochemical chromogens markers. In this study a melanin bleaching method was \\ developed aimed to allow the visualization of the chromogens without interfering in the \\ antigen-antibody affinity for immunohistochemistry. The analysis of PCNA (proliferating \\ cell nuclear antigen) index in the epidermis of $A$. australis by immunohistochemistry with \\ diaminobenzidine (DAB) as chromogen was used to test the method. The bleaching of the \\ melanin allowed to obtain the cell proliferation index in epidermis and to avoid false positive \\ results without affecting the immunohistochemical results.
}

INDEX TERMS: Pinnipeds, fur seal, immunohistochemistry, skin, melanin, cell proliferation.

RESUMO.- [Clareamento da melanina na epiderme do Lobo-marinho-sul-americano e sua aplicação na imunohistoquímica enzimática.] O Lobo-marinho-sul-americano (Arctocephalus australis) é um mamífero marinho anfíbio distribuído ao longo da Costa do Atlântico e do Pacífico da América do Sul. Esta espécie está bem adaptada a diferentes habitats devido à morfologia dos membros em forma de nadadeira e de seu sistema tegumentar. Estu-

\footnotetext{
${ }^{1}$ Received on March 30, 2010.

Accepted for publication on January 20, 2011.

2 Setor de Anatomia dos Animais Domésticos e Silvestres, Departamento de Cirurgia, Faculdade de Medicina Veterinária e Zootecnia (FMVZ), Universidade de São Paulo (USP), Av. Prof. Orlando Marques de Paiva 87, São Paulo, SP 055508-900, Brazil. *Corresponding author: paulasilvabio@usp.br

${ }^{3}$ Departamento de Patologia, FMVZ-USP, São Paulo, Av. Prof. Orlando Marques de Paiva 87, SP 055508-900.

${ }^{4}$ Facultad de Ciencias, Universidad de la República, Iguá 4225 Esq. Mataojo C.P. 11400 Montevideo, Uruguay.
}

dos imuno-histoquímicos são importantes para avaliar os mecanismos de adaptação da pele devido a diferencial expressão dos antígenos presentes no tecido dependendo da região da superfície corporal. Entretanto, sua epiderme altamente pigmentada (melanina) impede a visualização dos marcadores cromógenos utilizados na imunohistoquímica. Neste trabalho foi desenvolvido um método de clarear a melanina para permitir a visualização dos cromógenos sem alterar a afinidade antígeno-anticorpo para a imuno-histoquímica. A análise do índice do PCNA (proliferating cell nuclear antigen) na epiderme de A. australis, com diaminobenzidina (DAB) como cromógeno foi usada para testar o método. O clareamento da melanina permitiu obter o índice de proliferação celular na epiderme e evitar resultados falso-positivos sem afetar os resultados imuno-histoquímicos.

TERMOS DE INDEXAÇÃO: Pinípedes, lobo-marinho, imunohistoquímica, pele, melanina, proliferação celular. 


\section{INTRODUCTION}

The South American fur seal (Arctocephalus australis) is a semi-aquatic marine mammal that is distributed in both the Atlantic Ocean and Pacific Ocean of South America, from Rio de Janeiro-Brazil to Paracas-Peru peninsula (Bonner 1993, IBAMA 2001). They belong to the group of Pinnipeds, carnivorous that inhabits both terrestrial and aquatic environments (Berta \& Sumich 2006). The skin was indicated as one of the most important systems during marine mammals evolution (Reidenberg 2007). This system is poorly studied in pinnipeds, and the investigation is restricted to histological techniques for its morphological characterization (Montagna \& Harrison 1957, Ling 1974). The flippers of $A$. australis are used to ground locomotion on a rocky ground, but they also may be important for corporeal thermoregulation. There are still several questions concerning the microscopic structure and behavior of the epidermis in marine mammals, especially about structural and functional differences between the dorsal and ventral region of the flippers skin (Ling 1974). The enzyme immunohistochemistry (EI) technique may be a valuable tool to answers these questions by the study of the expression of skin cell proteins in different situations.

The El that uses the peroxidase as enzyme and DAB (3'3-diaminobenzidine tetrahydrochloride) as chromogen is a useful, cheap and the most commonly used method for studies about the expression of epidermal antigens that can be related to the skin functions and metabolism. DAB, however, is a dark brown marker and may be indistinguishable from the melanin granules, which also are dark brown. The DAB-based El technique is often applied to obtain the PCNA (proliferating cell nuclear antigen) index of epithelial cells. In the highly pigmented epidermis of the fur seal skin, however, the melanin granules and the DAB staining become very similar and may cause errors during observation. In fact, the presence of melanin granules is a common characteristic in marine mammals, especially in the basal layer of the epidermis, coincidently where the proliferative activity is higher (Ling 1974). Thus, it is necessary to develop a method that removes the melanin and allows the correct observation of the DAB staining, avoiding false-positive results.

The purpose of this work was to standardize a simple and efficient protocol to bleach the melanin in heavily pigmented tissues allowing the visualization of enzyme chromogens in immunohistochemical studies. Another requirement of this protocol is that the procedure does not interfere with antigen-antibody affinity and with the cell proliferation index evaluation. This technique could also be applied to El staining of cell proliferation antigens in melanocytic tumours of dogs and cats, which may contain large amounts of melanin.

\section{MATERIALS AND METHODS}

Skin fragments of Arctocephalus australis, from the reproducti-

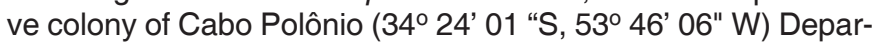
tamento de Rocha, Uruguay, were obtained in 2005 July. All animals used in this study died from natural causes and the collections of skin samples were authorized by Dinara (Dirección Nacional de Recursos Acuáticos do Uruguay) with help from the civil organización Profauma (Protección de la Fauna Marina). The research was approved by the Institutional Bioethics Committee (Protocol number 1066/2007).

The PCNA immunohistochemistry study was carried out in sequential pairs of $5 \mathrm{im}$ thick histological sections from skin fixed in Bouin solution for 24 hours and embedded in paraplast. Rat duodenum was fixed and embedded exactly in the same way as the skin fragments to be used as control. After dewaxing and rehydration, we followed the usual protocol for normal El: blocking of endogenous peroxidase with $3 \%$ hydrogen peroxide in methanol for 20 minutes, and demasking of antigens in a microwave oven $(720 \mathrm{~W})$ in $\mathrm{pH} 6.00 .01 \mathrm{~mol} / \mathrm{L}$ citrate buffer for 10 minutes.

The slides used for melanin bleaching were immersed in $10 \%$ hydrogen peroxide in $\mathrm{pH} 7.40 .2 \mathrm{~mol} / \mathrm{L}$ Tris- $\mathrm{HCl}$ buffer solution for 24 hours at room temperature. The staining jar was kept in the dark during this procedure. From this step on, both bleached and unbleached sections followed the same staining protocol. The unspecific reactions were blocked with the TNB blocking reagent (Tris-buffered reagent blocking) from the TSA staining kit (Amershan, Boston, USA) at $37^{\circ} \mathrm{C}$ for 30 minutes. The sections were thus incubated with monoclonal anti-PCNA antibody (Zymed, San Francisco, USA) diluted 1:200 in pH 7.4 Tris- $\mathrm{HCl} 0.2 \mathrm{~mol} / \mathrm{L}$ buffer solution overnight at $4^{\circ} \mathrm{C}$. After washing, the anti-mouse biotinylated secondary antibody was applied over the sections, followed by the streptavidin/peroxidase complex (both from kit LSAB DAKO, Glostrup, Denmark) for 30 minutes each at room temperature. The slides were incubated with DAB solution (kit LSAB DAKO) for 10 minutes at room temperature, counterstained by Harris hematoxylin and mounted with a permanent mounting medium. The same procedure was repeated in slides where the primary antibody was not applied (negative control). Each step of the procedure here described was preceded by three washes with $\mathrm{Tris}-\mathrm{HCl}$ buffer for five minutes each time.

Ten pairs of histological sections from the rat duodenum and another 10 pairs from the hindflipper skin of $A$. australis were either submitted or not to the bleaching procedure. Five hundred nuclei were randomly selected in each section and the number of PCNA-positive nuclei among the 500 selected was counted to calculate the cell proliferation index. All countings were done with an Olympus BX60 microscope (Carl Zeiss) under a 100x immersion oil objective by the same person. The mean of the total number of positive nuclei counted in the bleached section of each type of tissue were compared with the mean of the non-bleached sections using Student $t$ statistical test $(p<0.05)$.

\section{RESULTS}

The counting of PCNA-positive epidermal nuclei in paired sections of South American fur seal skin showed a significant difference between the samples that went through the melanin bleaching process by hydrogen peroxide and those that were not bleached. The statistical results are presented as mean \pm standard deviation. As can be noted in Figure 1 , the observer counted more PCNA-positive nuclei in the sections without bleaching $(139.0 \pm 16.7)$ than in the bleached $(85.90 \pm 23.3)$ sections $(p<0.05)$. 


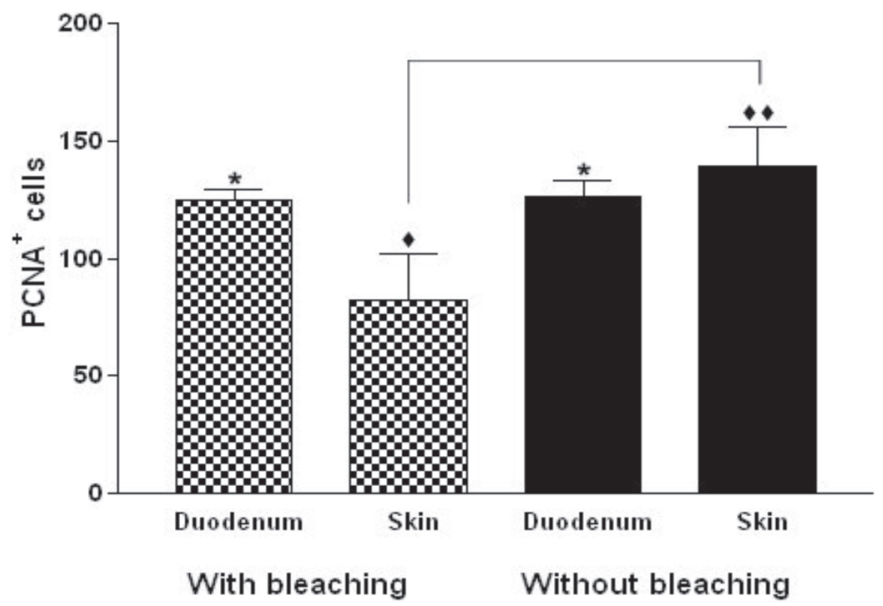

Fig.1. Counting of PCNA positive nuclei in histological sections of hindflippers skin of the South American fur seal and in rat duodenum with bleaching (chess pattern bars) and without bleaching (black bars) of melanin. Note that the mean of PCNA positive nuclei was lower in skin sections that were bleached, while the duodenum results remained the same with or without bleaching. Statistical Student t test $(p<0.05), \mathrm{n}=10$ sections. The means that are statistically different are joined by a line.
Figure 2 shows that in non-bleached epidermis the melanin granules were dispersed in the cytoplasm of the keratinocytes and sometimes they may be found masking the nuclei, making very difficult to differentiate a positive from a negative result. In duodenum, used as positive control of both PCNA staining and the bleaching procedure, no statistical difference of means could be shown between the number of positive nuclei counted in bleached (124.6 44.3$)$ or unbleached $(126.0 \pm 6.5)$ sections $(p<0.05)$. Also, we could not detect histological alteration or artifacts in the tissue after the bleaching process.

\section{DISCUSSION}

The melanin is one of a group of pigmented macromolecules from which the eumelanin and pheomelanin are part. These pigments are found in the epidermis and hair of mammals; however the melanin is the predominant form in marine mammals. The melanin is mainly found in organs that receive light and its function is cell photoprotection (Billingham \& Silvers 1960, Ling 1974). All types of melanin are formed by the conversion of tyrosine into $\alpha$-3,4-dihydroxyphenylalanine and then into dopaquinone and melanin by the enzyme

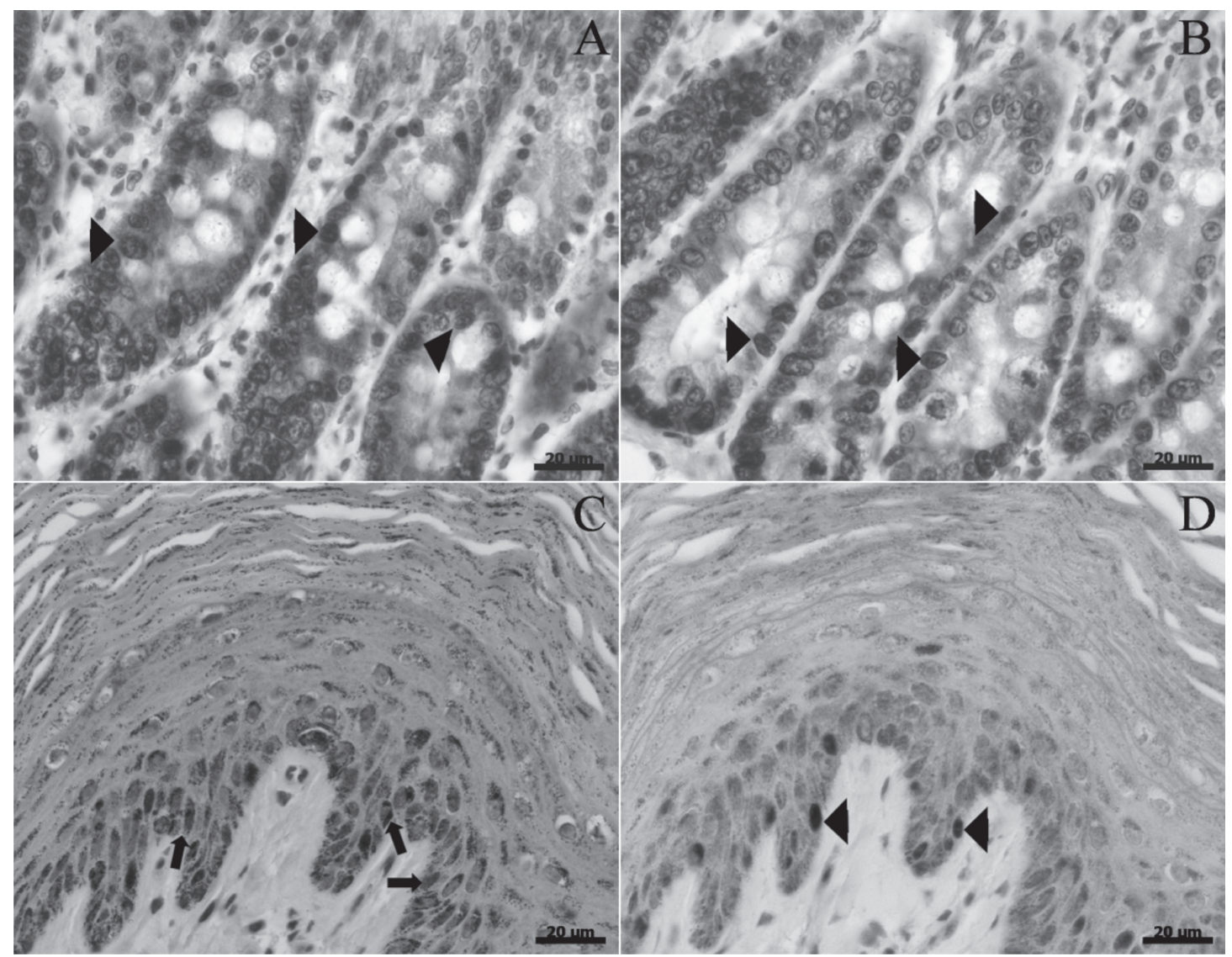

Fig.2. PCNA-positive nuclei after enzyme immunohistochemistry using DAB as chromogen (arrowhead). Hematoxylin counterstain. (A,B) Section of rat duodenum, mucosal glands region. (A) Without bleaching. (B) With bleaching. (C,D) Histological sections from South American fur seal skin. (C) Note the heavily pigmented epidermis slides without bleaching. The melanin granules in the cytoplasm and around the nuclei impair the correct observation of the chromogen (arrows). (D) Skin of the same region after bleaching, the positives and negatives nuclei may now be clearly distinguished. 
tyrosinase (Woolf \& Swafford 1988). The melanocytes, the melanin-secreting cells, are located in the basal layer of the epidermis, which is the mitotically active layer of this structure. They deliver the melanin granules to the cytoplasm of the keratinocytes (Ackerman et al. 2005). The granules are then transported to the supranuclear region, forming a protective barrier against ultraviolet radiation. The melanocytes from the skin and mucosal membranes are also involved in a very aggressive type of tumour, the malignant melanoma and there are several immunohistochemical studies directed to this tumor characterization (Li et al.1999, Roels et al. 1999) that would benefit from the bleaching of melanin to obtain a clearer microscopical image of the cells targeted by El research.

The bleaching protocol used in this work was successful in demasking the PCNA-positive nuclei from the melanin granules. The advantages of this procedure are noticeable when the results of nuclei counting are compared in both processes. It became evident that there were a high number of false-positives nuclei compounding the mean of the sections not bleached. The probable reason may be because the epidermal cells accumulate large quantity of melanin granules and several of these are over the nuclei, making difficult the differentiation between the brown DAB precipitates and the brown melanin. If the antigen targeted by IE is in the cytoplasm, the visualization of the chromogen would be worse due to the overwhelming presence of melanin in this cell region.

The lack of difference between the means obtained in the counting of duodenum nuclei, an organ where melanin is absent, confirms that melanin may infer with the observation of PCNA-positive nuclei. An important conclusion of the duodenum experiment is that bleaching of tissues by this method does not cause loss of antigenicity when it is applied to tissular PCNA antigens.

It is not the case of another method described in the literature, which consists of melanin bleaching with potassium permanganate and oxalic acid. The use of these products, before the primary antibody is applied over the sections, destroyed the epitopes to be studied. If these products were employed after the immunohistochemical reaction, the procedure removed the chromogen (Foss et al. 1995).

The bleaching of melanin occurs by its degradative oxidation by hydrogen peroxide (Korytowski \& Sarna 1990). In malignant melanoma studies (Li et al. 1999, Roels et al. 1999) used $10 \%$ hydrogen peroxide solution for 18 hours to bleach melanin at room temperature. However, their protocol had other substances, like bovine serum and disodium hydrogen phosphate and it was based on a report of Kivela (1995), who stated that the chromogen was not washed if the bleaching was done after the addition of the primary antibody. From our experiment we may conclude that the granules of melanin can induce even an expert observer to errors when analyzing DAB-based immunohistochemistry, overestimating the quantity of PCNA-positive nuclei. Here we could demonstrate a simple, fast and practical method to bleach melanin from animal tissues that can be safely applied to immunohistochemistry studies without alteration of the final results. Also, this technique of melanin bleaching may be the only alternative if counting of DAB positive nuclei is to be done in pigmented tissues by means of automatic computerized image analysis. Finally, other histological and histopathological studies in melanin-laden tissues from wild or domestic animals may benefit from the bleaching technique here described.

Acknowledgments.- The first author (A.P.Silva) was supported by a fellowship from Fundação de Amparo à Pesquisa do Estado de São Paulo (FAPESP, Proc.05/57640-5), and financial support was provided by FAPESP (Grant 06/05896-9). The authors are also greatly indebted to support of the Dirección Nacional de Recursos Acuáticos do Uruguay (Dinara), Facultad de Ciencias, Universidad de la República, Montevideo, Uruguay, and Protección de la Fauna Marina (Profauma).

\section{REFERENCES}

Ackerman A.B., Boer H., Bennin B. \& Gottlieb G.J. 2005. Histologic Diagnosis of Inflammatory Skin Diseases: An algorithmic method basead on pattern analysis. $3^{\text {rd }}$ ed. Ardor Scribendi, New York. 522p.

Berta A. \& Sumich J.L. 2006. Marine Mammals: Evolutionary biology. Academic Press, San Diego. 494p.

Bonner W.N. 1993. Southern fur seals Arctocephalus (Geoffroy SaintHilaire and Cuvier, 1826), p.161-205. In: Ridgway S.H. \& Harrison R.J. (Eds), Handbook of Marine Mammals: The walrus, sea lions, fur seal and sea otter. Vol.1. Academic Press, London.

Billingham R.E. \& Silvers W.K. 1960. The melanocytes of mammals. Quart. Rev. Biology 35(1):1-40.

Foss A.J.E., Alexander R.A., Jefferies L.W. \& Lightman S. 1995. Immunohistochemical techniques: the effect of melanin bleaching. Brit. J. Biomed. Sci. 52(1):22-25.

IBAMA 2001. Mamíferos Aquáticos do Brasil: plano de ação, versão II. Instituto Brasileiro do Meio Ambiente e dos Recursos Naturais Renováveis, Brasília. 96p.

Kivela T. 1995. Immunohistochemical staining followed by bleaching of melanin: A practical method for ophthalmic pathology. Brit. J. Biomed. Sci. 52(4):325-326.

Korytowski W. \& Sarna T. 1990. Bleaching melanin pigments: A role of copper ions and hydrogen peroxide in autooxidation and photooxidation of synthetic dopa-melanin. J. Biol. Chem. 265(21):1241012416.

Li Ling-Xi L., Crotty K.A., Kril J.J., Palmer A.A. \& McCarthy S.W. 1999. Method of melanin bleaching in MIB1-KI67 immunostaining of pigment lesions: A quantitative evaluation in malignant melanomas. Histochem. J. $31: 237-240$.

Ling J.K. 1974. The integument of marine mammals, p.1-42. In: Harrison R.J. (Ed.), Functional Anatomy of Marine Mammals. Vol.2. Academic Press, London.

Montagna W. \& Harrison R. 1957. Specializations in the skin of the seal (Phoca vitulina). Am. J. Anat. 100(1):81-113.

Reidenberg J.S. 2007. Anatomical adaptations of aquatic mammals. Anat. Rec. 290:507-513.

Roels S., Tilmant K. \& Ducatelle R. 1999. PCNA and Ki67 proliferation markers as criteria for prediction of clinical behavior of melanocytic tumours in cats and dogs. J. Comp. Pathol. 121:13-24.

Woolf C.M. \& Swafford J.R. 1988. Evidence for eumelanina and pheomelanin producing genotypes in the arabian horses. J. Heredity 79:100-106. 